Martin BOHUŠÍK ${ }^{1}$, Vladimír BULEJ ${ }^{2}$, Michal BARTOŠ³ ${ }^{3}$ Milan SÁGA Jr. ${ }^{4}$

Opiekun naukowy: Ivan KURIC ${ }^{5}$

DOI: https://doi.org/10.53052/9788366249837.31

\title{
ROBOTY HUMANOIDALNE WE WSPÓŁCZESNYM ŚWIECIE
}

\begin{abstract}
Streszczenie: W artykule opisano historię, stan obecny oraz zastosowanie robotów humanoidalnych na świecie. Roboty humanoidalne stają się coraz to bardziej podobne do ludzi, dzięki postępowi wiedzy w takich dziedzinach jak sztuczna inteligencja oraz systemy mechatroniczne. Rozwój robotów humanoidalnych oraz ich stosowanie w środowisku/otoczeniu ludzi (np. w produkcji, w hotelowych recepcjach, szkołach itp.) może powodować trudności w ich odróżnianiu od żywych i prawdziwych ludzi - w obu aspektach: wyglądzie oraz zachowaniu. Odnosi się to do kinematyki ludzkiego ciała oraz wykonywania poleceń, instrukcji.
\end{abstract}

Słowa kluczowe: robot humanoidalny, sztuczna inteligencja, system mechatroniczny

\section{HUMANOID ROBOTS IN THE WORLD}

Summary: The article describes the history, present and use of humanoid robots in the world. Humanoid robots are becoming more and more human-like, thanks to advanced knowledge of artificial intelligence and mechatronic systems. The development of humanoid robots and their implementation among humans (in production, receptions, schools, etc.) may make them difficult to distinguish from living humans - both in appearance and behaviour (the kinematics of the human body and the execution of instructions).

Keywords: humanoid robots, artificial intelligence, mechatronic system

\footnotetext{
${ }^{1}$ Ing., University in Žilina, Faculty of Mechanical Engineering, Department of Automation and Production Systems, e-mail: martin.bohusik@fstroj.uniza.sk

${ }^{2}$ Assoc.-prof., Ing., PhD., University in Žilina, Faculty of Mechanical Engineering, Department of Automation and Production Systems, e-mail: vladimir.bulej@fstroj.uniza.sk

${ }^{3}$ Ing., University of Zilina, Faculty of Mechanical Engineering, Department of Automation and Production Systems: michal.bartos@fstroj.uniza.sk

${ }^{4}$ Ing., University of Žilina, Faculty of Mechanical Engineering, Department of Automation and Production Systems, e-mail:milan.saga2@fstroj.uniza.sk,martin.bohusik@fstroj.uniza.sk ${ }^{5}$ prof. Dr. Ing., University of Bielsko-Biala, Faculty of Mechanical Engineering and Computer Science, Department of Industrial Engineering: kuric.ivan@gmail.com
} 


\section{Introduction}

Humans have been trying to build robots that look like humans for hundreds of years. Baked clay figurines of people in Europe and China made 7,000 years ago have been found. Egyptian civilization 3000 years ago, created articulated statues that could be controlled by hidden operators. For the selection of the new king at Thebes, an articulated statue of Amun - one of the major Egyptian gods, who was depicted as a man with a ram's head - was used. This statue was secretly controlled by the priests when male members of the royal family walked in front of it. Other creators of humanoid robots from the past include - Leonardo da Vinci (designed the mechanical equivalent of man - early 18th Century), Jacques de Vaucanson (constructed in 1737-1738 a flute player, and a tambourine player - are shown on the Figure 1), Pierre Jacquet-Drooz with son (constructed several humanoids, e.g. a female organist who simulated breathing and direction of gaze to look at the audience and at her hands during music - in the 18th century), Henri Maillardet (built a boy humanoid robot that was able to write text in both French and English, and could also draw different landscapes - in 1815. [1]

Today we have new knowledge about mechatronic systems and artificial intelligence. This is why humanoid robots are now being designed by companies to be able to use artificial intelligence - to categorise people in close contact, to process sound, to perform a certain task, etc. Companies and universities creating humanoid robots Hanson Robotics (Sophia), University of Geneva (Nadia), Osaka University (Erica), Honda Motor Company, Shadow Robot Company, Samsung Electronics, Google etc.
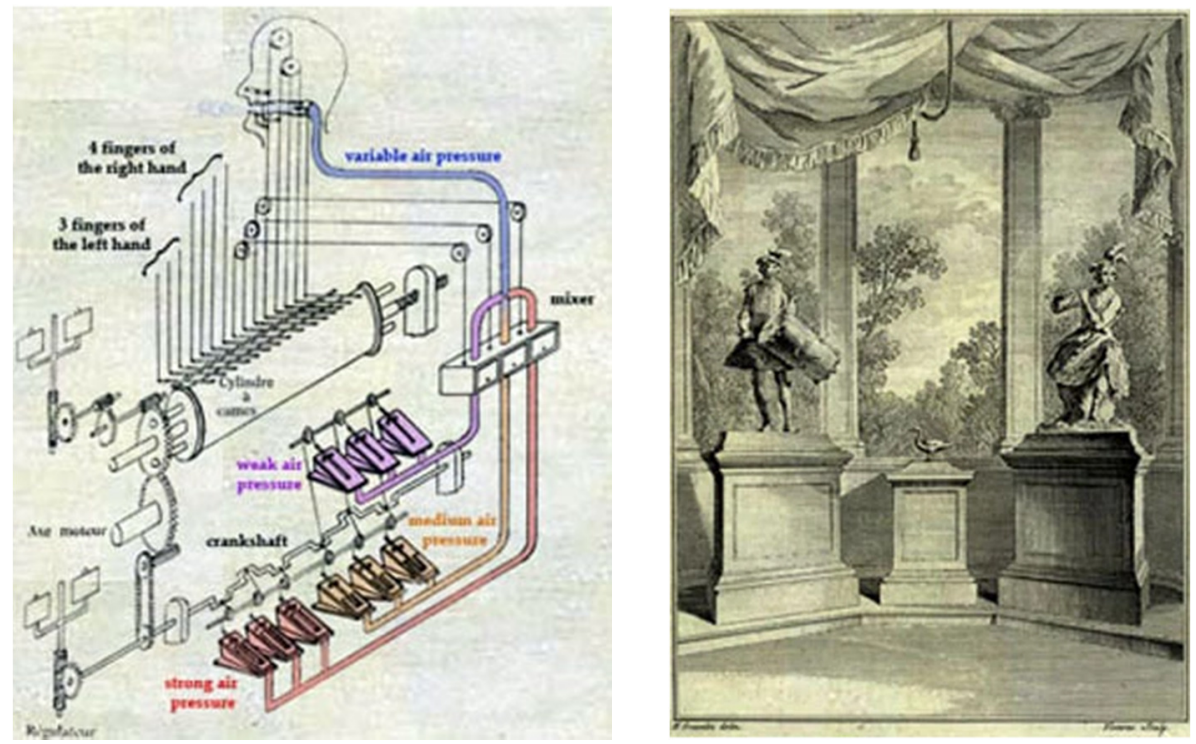

Figure 1. On the left side - flute player; on the right side-tambourine player [5] 


\section{The use of humanoid robots}

Humanoid robots, in their design and functions, are similar in appearance to ordinary humans. They should also behave like humans and have similar means of communication to humans. The pace of robotics development is rapid, and individual countries often encourage this development because of its potential to bring economic benefits to the country. For example, the workforce in Japan is declining significantly, seriously threatening Japan's economy, and it is robots that are seen as the current solution. In addition to using robots to produce goods, the aim is to use robots as cleaners, sales assistants, museum guides, carers for the young and old, presenters of TV programmes, and they could also work as teachers. [8]

Some uses of humanoid robots:

a) Robotic Avatar - The T-HR3 is a humanoid robot that, like a real-world avatar, mimics the actions of its human operator.

b) Robotic Ambassador.

c) Delivery Robot - The headless humanoid is equipped with agile limbs and a slew of sensors. It is capable of navigating stairwells, various obstacles, and varied terrains. It has the ability to pick up and stack boxes weighing up to 40 pounds. Delivery Robot is showed on Figure 2.

d) Robotic Bartender - Robotic Bartender Kime, who has been tested at gas stations around Europe and in a Spanish brewery, is reported to be quite good at pouring beer and can serve up to 300 glasses each hour.

e) Robonauts - Humanoids for space exploration are being developed by a number of countries. Microgravity tests will be conducted by the robot in order to help prepare for future crewed trips. Robonauts is showed on Figure 2.

f) Educational Robot.

g) And others... [6]
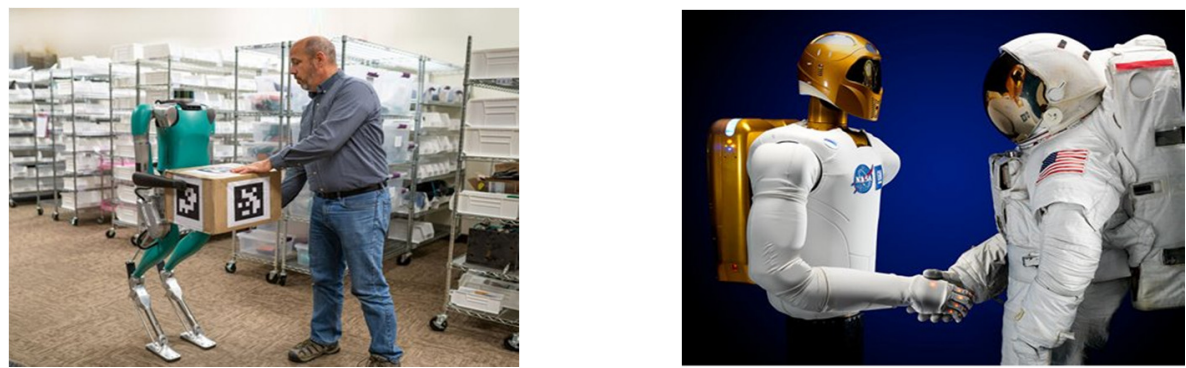

Figure 2. On the left side - Delivery Robot; on the right side - Robonauts [6]

The majority of the research is in the field of medicine. Humanoid robots were most commonly utilized to treat autism $(65 \%)$, diabetes $(15 \%)$, cancer $(10 \%)$, and cerebral palsy $(10 \%)$, as shown in Figure 3.. Humanoid robots reduced the severity of autism in youngsters and improved their social behavior and communication skills. Furthermore, using humanoid robots increased autistic children's collaborative behavior and learning ability, and interacting with robots made them feel entertained and at ease. Aside from successfully treating autism, humanoid robots have shown to 
be effective in diabetic education and reducing stress in pediatric cancer patients. Interacting with humanoid robots boosted the spirits of cerebral palsy patients. The robot's use also improved therapy efficiency by causing the patient and the therapist to pay attention to each other. [2]

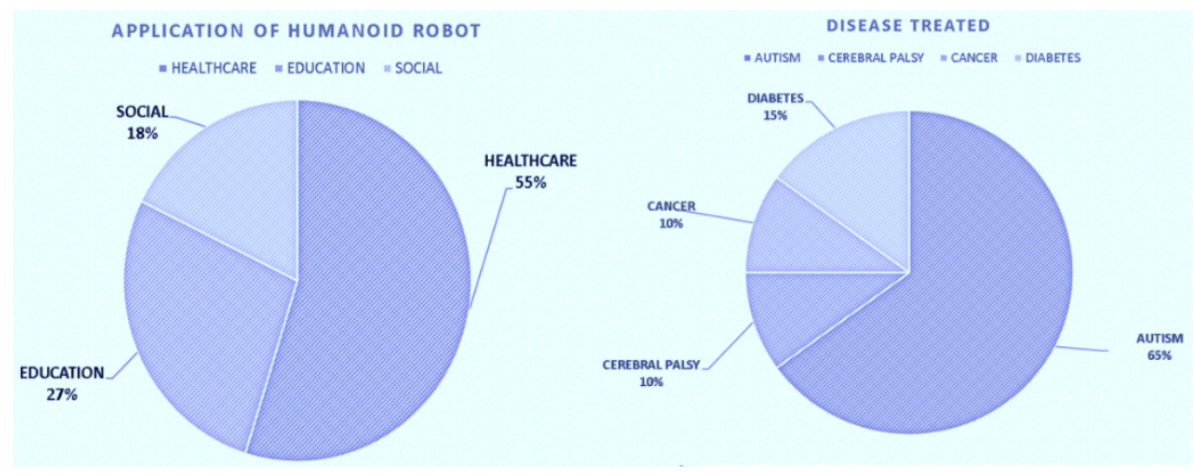

Figure 3. On the left side - the use of a humanoid robot; on the right side-diseases treated using humanoid robot [2]

\section{Sensors for mobile robots}

Humanoid robots contain a number of different sensors for acquiring data in the robot's environment and from its internal devices.

To categorize sensors using two key functional axes: proprioceptive/exteroceptive and

passive/active.

a) Proprioceptive sensors - Internal values of the system (robot) are measured, such as motor speed, wheel load, robot arm joint angles, and battery voltage. Sensors - encoders, accelerometers, gyroscopes, tilt sensors, force sensors, position sensors etc.

b) Exteroceptive sensors - Obtain data from the robot's surroundings, such as distance measurements, light intensity, and sound amplitude. As a result, the robot interprets exteroceptive sensor signals in order to extract significant environmental information. Sensors - sonar, range lasers, cameras, gps etc.

c) Passive sensors - detect the amount of energy that enters the sensor from the environment. Temperature probes, microphones, and CCD or CMOS cameras are examples of passive sensors.

d) Active sensors - Sensors release energy into the environment and then measure the response. Active sensors frequently outperform passive sensors because they can manage more regulated interactions with the environment. Active sensing, on the other hand, comes with a number of drawbacks: The outbound energy may have an impact on the qualities that the sensor is trying to detect. [12] 


\section{Most advanced social humanoid robots}

Nowadays, many companies and universities are involved in the production of humanoid robots. The subsections below, show a few humanoid robots that have the most advanced capabilities.

In each situation, a social robot would need to be able to detect both verbal and nonverbal indications from humans it encounters and adjust its own verbal and nonverbal behavior accordingly. Another prerequisite would be a comprehension of its surroundings, which would enable it to do various duties and navigate if necessary.

\subsection{Nadine}

Nadine contains separate modules for face recognition, gaze behavior, speech recognition and synthesis, action recognition, object recognition, user memory, affective system (to represent her personality, emotion, and mood), data processing, and dialog system to ensure her smooth operation. Nadine featured built-in chatbots that allowed her to answer a variety of questions, as well as a memory model that remembered different people and their chats. Nadine is showed on the Figure 4. [4,9]
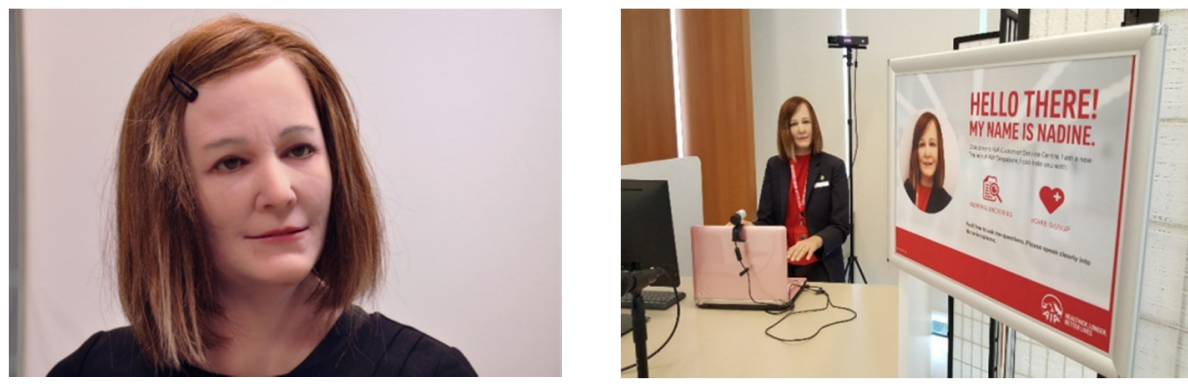

Figure 4. Nadine Social Robot [9]

\subsection{Sophia}

Hanson Robotics has created one of the most human-like humanoid robots in existence today. This humanoid robot is called by the name of "Sophia" (showed on Figure 5.).
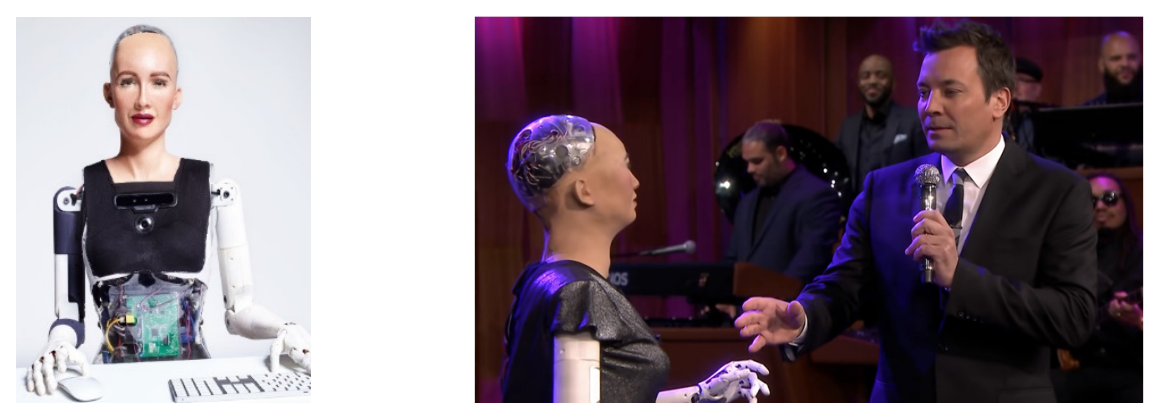

Figure 5. Humanoid robot - Sophia [3] 
Sofia is the world's first robot citizen, and the first Robot Innovation Ambassador for the United Nations Development Programme. Sofia currently speaks at hundreds of conferences (as well as on various TV shows). Its artificial intelligence combines work from the fields of neural networks, expert systems, machine perception, natural language processing, motor control, and cognitive architecture. Sofia is able to recognise human faces, see emotional expressions and also recognise different hand gestures. It can also estimate the feelings of the people with whom it communicates (directly during the conversation) and tries to find a way to achieve certain goals of communication with the communicating people. It has its own emotions that roughly simulate human evolutionary psychology. [3]

\subsection{Erica}

Erica is a high-tech android that was created as a research platform for studying human-robot interaction. It understands in natural language, has a human-like voice, and can make a range of facial expressions. Erica has 15 infrared sensors implanted into her "eyes" that can track any movement. She also features speech-generation algorithms and facial recognition technology, which allows her to monitor many faces in a room with ease. Erica has forty-four degrees of freedom incorporated into her face, neck, and waist, allowing her to make a variety of facial expressions. And, while she is still unable to move her arms, it is not a major issue because she works as a news anchor. Erica is showed to Figure 6. [11]

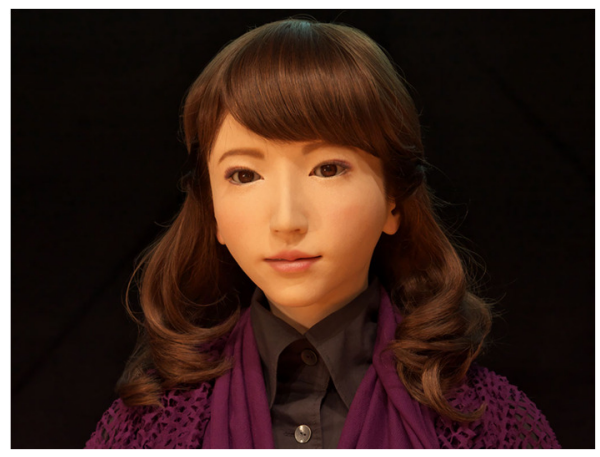

Figure 6. Humanoid robot Erica [11]

\subsection{Junko Chihira}

Toshiba built Junko Chihira, a lifelike humanoid robot that will work in a new tourist information center in Japan. According to a press release, the bot can speak Japanese, Chinese, and English and made her debut a few weeks ago in Aqua City Odaiba, a shopping district on Tokyo's waterfront. Junko Chihira now greets guests as they enter, but beginning in December, the android will be able to give travelers with information about upcoming events in the neighborhood. Junko Chihira is showed on Figure 7. [7] 


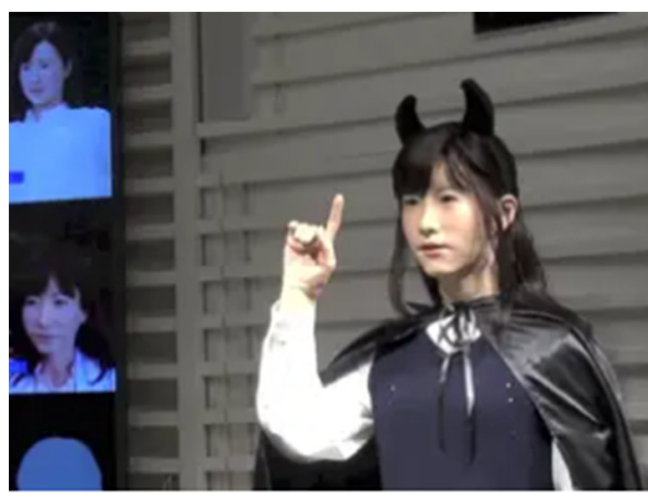

Figure 7. Junko Chihira [7]

\subsection{Jia Jia}

University of Science and Technology of China produces the Jia Jia humanoid robot. Jia Jia is the first humanoid robot created in China. Her flexible plastic face gives her a realistic appearance. Jia Jia's expressions are so lifelike that special emphasis was placed on her "eyes" so that she can pick up on varied gestures, emotions, behavior, and so on and respond appropriately. She also features speech-generation algorithms that enable her to converse with humans, as well as facial recognition technology that allows her to track many faces in a room. Jia Jia is showed on Figure 8. [4,10]

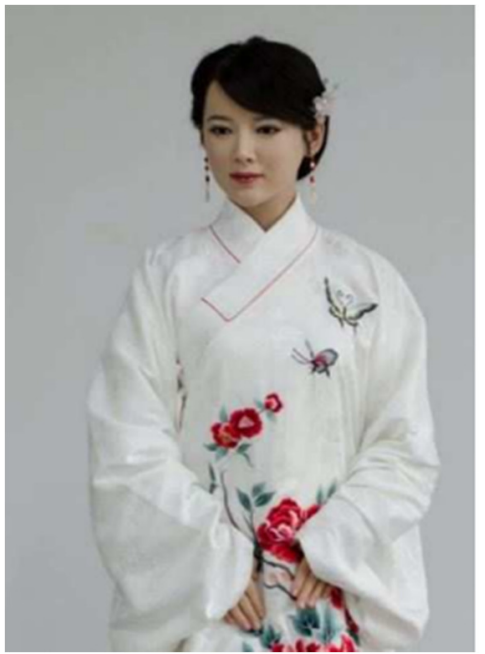

Figure 8. Jia Jia Humanooid Robot [10]

\subsection{Humanoid eye design}

The project we are currently working on at the Department of Automation and Production Systems is the design of humanoid eyes. Humanoid eyes are used in the creation of humanoid robots as a means of perceiving the surrounding world in which the robot finds itself. By placing cameras in humanoid eyes, the control unit 
(RPi) and through machine vision, it is possible to control the devices by gestures, categorize the sensed objects, track the object, etc. The design of the humanoid eye structure is shown on Figure 9.. The components used in the design are: 2x SG90 servomotors; 7x M3x15 screws; 1x M2x30 screw; printed components from 3D models on a $3 \mathrm{D}$ printer.

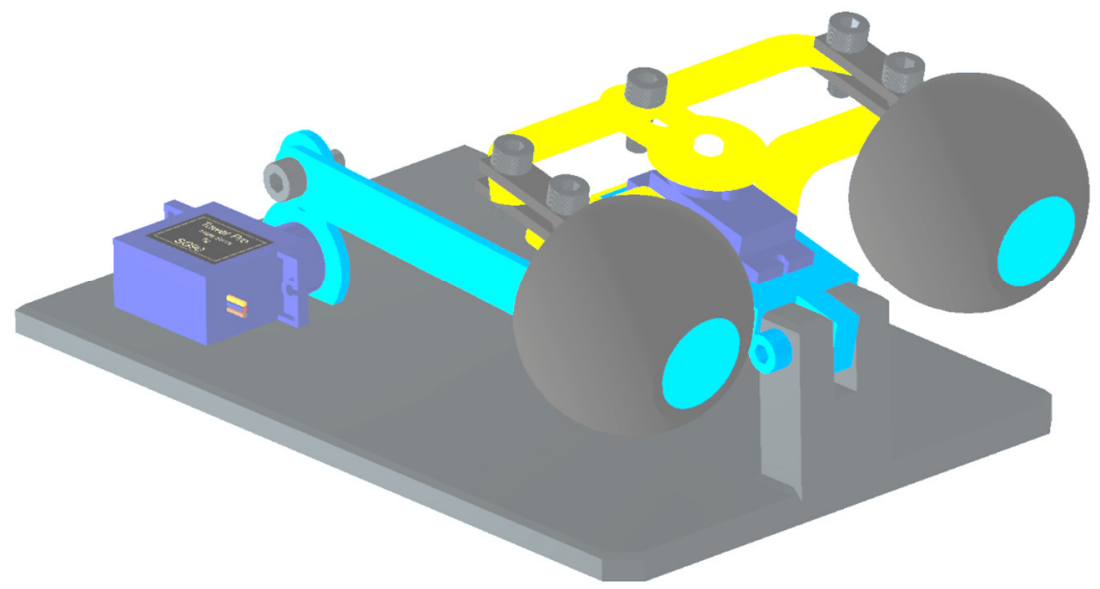

Figure 9. Humanoid eye design

\section{Conclusion}

The article deals with humanoid robots and their use in everyday life. It is expected that humanoid robots will be increasingly implemented in people's daily lives. These robots can replace living humans in certain applications and, in some cases, save human lives. Due to the continuous development of humanoid robots, we decided to create a stereovision mechatronic system - humanoid eyes. This project is still in the design phase - we are still working on this project.

\section{ACKNOWLEDGEMENT}

This work was supported by the grant agency KEGA, project no. 042ŽU-4/2020 Building up a specialized laboratory for mechatronic systems to improve the teaching of the newly-accredited subject Mechatronic Systems; and by Grant System of University of Zilina No. 1/2021 (14892). 


\section{REFERENCES}

1. BROOKS, R.: Humanoid Robots. Available on: https://dl.acm.org/doi/pdf/10.1 145/504729.504751, 2002.

2. CHOUDHURY, A.; HUIYANG, L.; GREENE, CH. M.; PERUMALLA, S.: Humanoid Robot - Application and Influence. Available on: https://arxiv.org/ft p/arxiv/papers/1812/1812.06090.pdf, 2018.

3. HANSONROBOTICS: Sophia. Available on: https://www.hansonrobotics.com /sophial, 2021.

4. HARKIRAN, K.: 5 Best Humanoid Robots in The World. Available on: https:/ /www.geeksforgeeks.org/5-best-humanoid-robots-in-the-world/, 2021.

5. HISTORY-COMPUTER: Jacques de Vaucanson - Complete Biography, History and Inventions. Available on: https://history-computer.com/jacques-devaucanson-complete-biography/, 2021.

6. MERKUSHEVA, D.: 10 Humanoid Robots of 2020. Available on: https://www .asme.org/topics-resources/content/10-humanoid-robots-of-2020, 2020.

7. MUOIO, D.; INSIDER, T.: Toshiba's latest humanoid robot speaks three languages and works in a mall. Available on: https://www.businessinsider.com/ toshibas-humanoid-robot-junko-chihira-speaks-three-languages-2015-11, 2015.

8. NEWTON, Douglas P a Lynn D NEWTON, 2019. Humanoid Robots as Teachers and a Proposed Code of Practice. Frontiers in Education [online]. 2019, roč. 4, pp. 125. ISSN 2504-284X. Available on: doi:10.3389/feduc.2019.00125.

9. RAMANATHAN, M; MISHRA, N. THALMANN, N. M.: Nadine Humanoid Social Robotics Platform. Available on: https://www.researchgate.net/publicati on/333706136_Nadine_Humanoid_Social_Robotics_Platform, 2019.

10. RIAZ, M; NAWAZ, I. SOHAIL, M.: Novel Concepts of Soft Multi Rough Sets with MCGDM for Selection of Humanoid Robot. Available on: https://www.researchgate.net/publication/339374797_No vel_Concepts_of_Soft_Multi_Rough_Sets_with_MCGDM_for_Selection_of_H umanoid_Robot, 2020.

11. ROBOTS: Erica. Available on: https://robots.ieee.org/robots/erica/, 2015.

12. SIEGWART, R.; NOURBAKHSH, I.: Autonomous Mobile Robots. Available on: http://www.cs.cmu.edu/ rasc/Download/AMRobots4.pdf.

13. Social Robotics Platform. Available on: https://www.researchgate.net/publicati on/333706136_Nadine_Humanoid_Social_Robotics_Platform, 2011. 
